\title{
A brief Introduction of Ex-Royal Nepal Army Doctors and Technical Medical Officer's Society (ERNADTMOS)
}

\author{
Brig. Gen. (Retd.) Dr. Nayan Bahadur Subedi \\ President, ERNADTMOS
}

With the noble intention of meeting th retired colleagues and friends who worked in the same institutiuon for many years, on the 19th of Ashad 2056 a social get-together was organized at hotel de'la Annapurna. Many friends with their spouses attended the social gathering, and among them were Lt. Col. (Retd.) Dr. and Mrs. Mohan Gopal Baidya. Sadly both of them passed away after that meet. We pray for their eternal peace.

During the first social meet a need to have such a get-together on a regular basis was felt. In order to organise these types of meet and also to explore the possibilites for carrying out various other activities a need for a society of doctors and technical medical officers was felt. It was thus unanimously decided to form a society. To give this society a formal name and fulfilled basic criteria of social organizations a second meet of all the retired doctors and technical medical officers were organized at hotel Royal Singhe. It was heirtening to note that many attended this gathering and a society named EX-Royal Nepal Army Doctors and Technical Medical Officers Soceity "ERNADTMOS" was formed- On the same day membership drive was carried out and 17 people took life membership immediately. The society was registered at Lalitpur CDO office on the 17th of Chaitra 2056. On 24th Baisakh 2057 election for the various executive posts were held. The first executive members were elected uncontested.

This society was intially formed with the conception of "Meet the friends" program and to this on the enthusiastic suggestions of all the members further activities such as to provide medical serives to the community in general and retired army personnel and their families in particular was added. To give continuity to our objectives first free health camp was organized in the premises of shree Bal Kumari Secondary School of Sunakothi VDC of Lalitpur on the 28th of Magh 2057, more than 700 patients of all ages were examined and medicine were distributed free. Similar free health camp will be organized in a regular basis in different locations.

We celebrated our First Anniversary on the 17th of Chaitra 2057 amidst various functions. All themembers with their spouses, friends and well wisher attended the functions Doctor Suresh Raj Sharma Vice Chancellor of Kathmandu Unviersity was our Chief guest. The first Souvenir of ERNADTMOS was issued and life membership certificate was distributed to all our members.

The formation of "ERNADTMOS" has been a common platform for all of us who have retired from Royal Nepal Army Medical Corps. We all can be of immense help even after retirement and Community can make use of our abilities for the betterment of all mankind.

\section{First Executive Committee of ERNADTMOS (2057-2059 B.S.)}

President

Vlce President

General Secretary

Treasurer

Members

$\begin{array}{ll}\text { - } & \text { Dr. Nayan Bdr. Subedi } \\ \text { - } & \text { Dr. Vijaya Bdr. Rajbhandary } \\ \text { - } & \text { Dr. Baikuntha Karmacharya } \\ \text { - } & \text { Dr. Amrit Bdr. K.C. } \\ \text { - } & \text { Dr. Pathar Lal Shrestha } \\ \text { - } & \text { Mrs. Shashikala Rajbhandary } \\ \text { - } & \text { Mrs. Krishna Sharma }\end{array}$

\section{Address ERNDTMOS}

Smriti Bhawan, Taphalohn, Jawalakhe, Ward No. 5, Lalitpur

GPO Box No. 7504 (Kathmandu) Nepal

E-mail: drnbs@ @ealthnet.org.nt 